\title{
Disclosure of Relevant Acts or Facts: A Study of Brazilian Companies Issuing American Deposit Receipts - Adrs at American Stock Exchanges
}

\author{
Ludmila Lavorato Loures \\ Professor FUMEC University \\ Professor of Public Accountability and Finance Management \\ Researcher in finances information. Brazil
}

Carlos Alberto Gonçalves

Full professor at Universities FUMEC e UFMG

Professor of Strategic Management and Innovation Performance

Coordinator of NUME - Research Center of Strategy and Innovation

Researcher in subjects Strategic Performance

factors that imply firms innovation growth. Brazil

\section{Daniel Jardin Pardini}

Full professor at FUMEC University

Professor of Strategic Management and Corporate Governance

Researcher on strategic themes in Policy and Strategic Public Governance. Brazil

\begin{abstract}
The aim of this article identifies, evaluates and describes relevant facts and acts' occurrences disclosed by Brazilian companies issuing ADRs - American Depositary Receipts. The analysis was made based on 1,125 information extracted from the Comissão de Valores Imobiliários - CVM's website, the regulatory commission organization empowered to regulate, standardize and supervise the activities of trade agents of public securities in Brazil. The research used information that was carried out from January 2006 to April 2012. It was evidenced that companies whose trade their depositary receipts in markets with high standards of corporate governance practices do not disclose a larger amount of information than the lower one governance practices. This research expands the knowledge about the content, frequency and timing of disclosure of relevant information by Brazilian organizations in international equity markets.
\end{abstract}

Key Words: Corporate Governance. Relevant organizational information. ADR. American Depositary Receipts.

\section{INTRODUCTION}

One of the great dilemmas in the literature dealing with the accounting data management relates to how and when to disclose them. Ansoff and McDonnell (1993) show that organizations are faced with complex situations when the decision of disclosing information or not is in play. There is often a need for safeguarding it, since exposing the business intention may undermine the strategy underlying the operation. On the other hand, it dictates the principles of good governance and the relevant legislation that the relevant facts must be reported promptly to the interested parties, being prohibited the retention of privileged information. 
This research aims to increase knowledge about how the open capital Brazilian organizations structure and practice the disclosure of information of relevant acts and facts. Not much has been researched on the recurrence and the type of information that these organizations disclose to stakeholders in their activities. Although they are common studies relating to disclosure and the impact on the capital market, (BROWN, THEODORE; CHRISTENSEN; BROOKE, 2012; SILVA, FELIPE, 2010; LOPES; VALETIM, 2008) researches dealing with the narrative content of these reports and their timing are still incipient. (DAVIS; PIGER; SEDOR, 2012).

Some companies are reluctant to publish their information. Several may be the factors that lead companies not to disclose information completely. Often, such maneuvers are motivated by fear of having the strategic organizational objectives jeopardized. On the other hand, companies are faced with the need to follow the disclosure guidelines of the relevant facts, a situation which imposes the dilemma between the risk of informing the market and the principle of transparency. From the perspective of governance, this study aims to analyze the guidelines of the mandatory disclosure of information related to material facts and acts of Brazilian companies that trade securities on US stock exchanges.

The internationalization of capital markets and the increase of foreign capital in the domestic stock market have driven new thinking on how to disseminate information of interest to major public organizations. Open capital Brazilian companies that have chosen to internationalize their operations had to adapt to the legal guidelines of the domestic and international markets. In Brazil, the law of joint-stock companies, the instructions of the CVM - Brazilian Securities Commission and regulations and the listing segment at BM \& FBOVESPA led companies to adopt a series of procedures in the provision of information to shareholders and the market. In the case of the conditions to negotiate ADRs - American Depositary Receipts, the guidelines issued by the Sarbanes-Oxley (SOX), the Security and Exchange Commission (SEC) and the recently established Dodd-Frank law meant that companies should also meet the US law requirements.

The intensification of international legal pressure on the disclosure of material information refers with the question whether, in fact, the regulatory requirements and inspection of national and international markets for equity have been complied. The objective of this article is then to identify, assess and describe the frequency and content of the relevant information disclosed by Brazilian public companies issuing ADRs - American Depositary Receipts.

It is intended to verify if there prevails a higher recurrence of disclosure of relevant events by those organizations that operate specifically in markets that require high level of transparency of information. The sectors that disclose relevant acts and facts and the possible relationships between the frequency of dissemination of information, the size of organizations and types of markets in which they operate should also be identified.

\section{DISCLOSURE OF RELEVANT INFORMATION: CONTENTS, DECISION MAKING, AND LEGAL ASPECTS OF CORPORATE GOVERNANCE}

In studies dealing with the disclosure of information to organizations' investors, some studied fields can be identified: research on the content of the texts published (Defond; HUNG; Trezevant, 2007; DAVIS; Piger; SEDOR, 2012; LOPES, VALENTINE, 2008 ; SILVA, FELIPE, 2010), research dealing with the decision to release or not the reports (BROWN, THEODORE; CHRISTENSEN; BROOKE, 2012; SON; CRABTREE, 2011; OLIVEIRA; LOPES, CUNHA, 2008) and works that address the governance principles that support the disclosure policy of publicly 
traded organizations in the securities markets (Shleifer and Vishny, 1986; Lanzana; SILVEIRA; Fama, 2006; FRANCIS; SCHIPPER; VINCENT 2002). This topic covers these investigative cutouts.

\section{Relevant Information Content}

Companies have three types of information flow (LESCA; ALMEIDA, 1994, p 07.): a) externally collected; b) the information produced by the company and intended for the company itself; and c) the data generated in the organization and disclosed to the market. Living with external actors and the publication of information to the outside world are strategic factors for the organization (FRANCIS; SCHIPPER; VINCENT 2002). In the capital market, a major recipient of organizational data, the explicit content of the information disclosed aims to bring the investor to the reality of the organization, so that we can identify investment opportunities and take forward decisions to the scenarios set out in communications (LOPES; VALENTINE, 2008).

Some of the research on the informational content announced to the market have focused on readability of the data provided and the impact that information has on the value of the shares (DAVIS; Piger; SEDOR, 2012; LOPES, VALENTINE, 2008; Bhattacharya; BLACK; CHRISTENSEN; Mergenthaler, 2007). The content of information to the market also finds relations with institutional protection levels assured. Research conducted in 26 countries shows evidence that the relevant information announcements are more informative in countries with strong protection for institutional investors (Defond; HUNG; trezevant, 2007).

Studies concerning the acts and facts of Brazilian companies, indicate that the information disclosed in the Brazilian market is still difficult to read and, over the years, have become more extensive and less widespread (SILVA; FELIPE, 2010). In another way, it is still clear the need for other administrative, strategic and financial communications, besides financial reporting, that support the real understanding of the company's situation (OLIVEIRA; LOPES; CUNHA, 2008).

\section{To disclose or not to disclose relevant information? "That is the question"}

It is one of the dilemmas that have supported the management of information dissemination and which relevant reports should or should not be disclosed to the market. What will determine the company's decision to communicate or fail to report a relevant fact are the possible consequences for their competitive niche (BROWN, THEODORE; CHRISTENSEN; BROOKE, 2012; LOPES, VALENTINE, 2008). To Oliveira ET. Al (2008) the relevant data announcement helps to reduce capital costs, increases credibility with the public and the liquidity of traded securities. Moreover, the publication of accurate, complete and timely information on important facts reinforces investor confidence and allows forming a more informed judgment of the performance and the assets of the organization (OLIVEIRA; LOPES, CUNHA, 2008).

Disclosure of information relating to relevant acts and facts acquire greater or lesser importance depending on the size and the company's emphasis on the capital market. Its importance can be measured by the liquidity of the shares and measured by turnover and daily movement of papers (Shleifer, Vishny, 1986). The range of information to the investor's disposal is important to weigh the risk and return on investment. Thus, companies must decide on disclosing any relevant act or fact, subject to cause surprises to the market.

In another direction, some authors also highlight the benefits of not disclosing the relevant statement. Lesca and Almeida (1994, p. 06) point out that some companies manage information as a strategic resource, but "have no desire to see their name written, as is 
preferred to discreetly keep their strategic asset." The more detailed the information disclosure, the greater the chances of creating a competitive disadvantage (OLIVEIRA; LOPES, CUNHA, 2008). The development and dissemination of an information strategy should take into account the possible risks related to its publication on the competition. The option to decide not to disclose strategic information can be explained by the very secrecy that is often adopted in the strategy creation and development (BROWN, THEODORE; CHRISTENSEN; BROOKE, 2012). Including the strategic aspect, the disclosure incurs costs related to the processing of information, the cost of auditing and those expenditures that indirectly affect the company as trading with customers, employees, suppliers and government (SON; CRABTREE, 2011).

Regardless of the prevailing duality of the advantages of full disclosure of relevant information about the company and the reluctance to disclose strategic information, companies have tried to improve the mechanisms for providing information to its stakeholders (shareholders and other stakeholders) in order to reduce the apprehensions of those who depend on or participate in the daily activities of the organization. One of the areas of study that deals with the way and the effects of disclosures of organizational information is corporate governance that will be addressed in sequence.

\section{A Corporate Governance and Information Disclosure}

Corporate governance can be understood as a set of mechanisms to ensure the suppliers of capital that their investments will receive an adequate return; protection including creditors and minority shareholders (Shleifer, Vishny, 1986). Same position is shared by Grun (2003) by stating that the company's relations with the capital market, the exercise of good governance embraced by the accounting transparency and respect for the rights of minority shareholders.

In relation to the act of providing important information to the market, beyond the term transparency, two other terms are used in the literature: evidence and disclosure. Evidencing refers to information covered with quality, reliability and clarity; disclosure, the specific requirement of US law for companies listed on stock exchanges to disclose information, seeking greater ethics and transparency in business (FRANCIS; SCHIPPER; VINCENT 2002; Lanzana; SILVEIRA; Fama, 2006). Evidencing then is a way to achieve transparency. Disclosure will be obtained if there is clarity of the content to be provided at the ideal time of information dissemination to the interested public (Schrand; WALTHER, 2000).

The level of transparency in communication is nevertheless also an important indicator of good corporate governance practices (FRANCIS; SCHIPPER; VINCENT 2002). The requirements in relation to its exercise will depend on the relevant legislation to the locus of trading securities.

\section{Legal Aspects of the Relevant Information Disclosure in Brazil and the United States}

Some legal instruments are worth mentioning when the central theme is the relationship between companies and their public and the market: in Brazil, Law 6,385 / 76, which created the Comissão de Valores Imobiliários (CVM) and, in the international stock market, American laws Sarbanes-Oxley, of 2002 and the Dodd-Frank, of 2010. In the case of the Brazilian legislation, the regulations on information disclosure relating to relevant acts and facts are in charge of the Brazilian Securities Commission - CVM. The concept of relevant act or fact refers to any decision of the controlling shareholder; it involves the resolutions of the general meeting, the board of directors of the public company, or any other political-administrative, 
technical, economic and financial information related to the organization's business (CVM, 2002).

In this paper it was also adopted the terminology relevant acts (emphasis added) and facts in order not to denote the exclusionary meaning of the conjunction. Relevant acts and facts refer to the decisions of investors to buy, sell or hold securities and exercise any rights inherent to the condition of holder of these securities (DAVIS; Piger; SEDOR, 2012). The Securities and Exchange Commission provides a list of 22 relevant acts or facts (CVM, 2009) to be research objects in this research.

For cases of non-disclosure of relevant information, the company must justify the procedures adopted for the maintenance of secrecy about those important data not disclosed. If disclosure of the relevant information put the organization at risk, or if the relevant act or fact is not mature enough to be disclosed, administrators can maintain confidentiality regarding such information. In these cases, companies must monitor the trading of securities issued by it, so that they can identify any atypical fluctuations in price, volume or amount of their business titles. (CODIM, 2008). In addition to the periodic financial statements that open capital companies must disclose, it is also required the communication of information of narrative content that transmits events not included in the financial information (BRAZIL, 1976).

At an international level, the US laws Sarbanes-Oxley (SOX), and more recently, the DoddFrank (2010) have been the subject of attention of the public companies. The SOX emerged from the need to organize the rules on disclosure and financial reporting that converge to good corporate governance practices. The purpose of SOX is to restore market balance, through mechanisms to ensure senior management responsibility for the reliability of the information provided (BOWEN, DAVIS; MATSUMOTO, 2005; Borgerth, 2007). The Dodd-Frank, among other important provisions, punishes bribery of politicians and rewards whistleblowers demanding unique information that proves fraud (POLK, 2010). Public companies whose shares are traded on US stock exchange market, specifically on the New York Stock Exchange (NYSE) and NASDAQ (National Association of Securities Dealers Automated Quotations) are all included in the law.

Therefore, foreign companies that have open capital in the United States should provide financial and other relevant information to organizational structure, risk factors affecting the operations of the organization and relating to shareholders and corporate governance. Monitoring the disclosure of such information is held by the SEC (Security and Exchange Commission). For the SOX requirements to be met, companies with registration in the US capital markets should have a clear and reliable communication process with investors, financers and other stakeholders in their performance.

As for Brazilian companies issuing ADRs - American Depositary Receipts, they are subject to the requirements of Sarbanes-Oxley, Dodd Frank and the rules of US stock markets. ADRs are securities representing shares or other securities representing rights and shares issued abroad by those institutions called depositories. Issued and traded on the US capital market (USA), the ADRs are backed by shares of a non-US company. In the specific case of this article, it is intended to check the frequency and content of the relevant acts and facts reported by Brazilian companies that operate in this market.

\section{METHODS ADOPTED}

To evaluate the disclosure of occurrences of relevant acts and facts of Brazilian public companies issuing ADRs descriptive statistics were utilized. The choice of method is due to the 
provided statistical tools that make it possible to synthesize a series of related values, allowing them to have an overview of numerical data through tables and descriptive measures (GUEDES; MARTINS, 2010; MOSQUE, 2010). The group of companies chosen was composed by Brazilian companies registered with the CVM that had, in 2012, registration with the SEC Securities and Exchange Commission. The analysis of the relevant facts covered the information available on the CVM website from January 2006 to April 2012, with the basic orientation to CVM Instruction 358/02.

Thirty-four (34) Brazilian organizations issuers of ADRs Levels 2 and 3 mandatorily deposit their information with the SEC on Form 20-F were identified. From the group companies subject to the requirements of the Sarbanes-Oxley Act (2002) and the rules of the major US stock exchanges, Telebras as a result of the company's exemption file the 20-F report was excluded. Banco Itau Holding Financeira S/A and Unibanco (União de Bancos Brasileiros S/A), due to the merger of these institutions, they were analyzed under the name of Itaú Unibanco Holding S/A. The same procedure was adopted for Perdigão S/A, after the corporate restructuring, it received the name of BRF - Brazil Foods S/A. Banco Santander Brazil that in 2011, joined this small group, was also added. Thus, from the group of organizations, 33 were part of the survey, distributed in five economic sectors: 10 of industry, 6 of natural resources, 5 of services, financial services account for 3 and 9 of telecommunications.

In the first stage of the research 1,125 relevant acts or facts of these 33 companies were collected and recorded from the CVM website. The second stage of work was the examination and classification of each of the 1,125 facts. Much of the information recorded in the CVM database does not match the items of normative instruction, which required interpretative analysis for classification. The list, then, shows the acts or facts used and the reasons for the incorporation of other events.

List of 23 items relating to relevant facts of CVM Instruction 358/02 and other facts framing justifications.

1. Signing of agreement or contract of transfer of control of the company, even if under suspensive or resolutory condition.

2. Change in control of the company, including through the execution, amendment or termination of shareholders agreement.

3. Execution, amendment or termination of shareholders agreement in which the company is a party or intervener, or has been entered in the company's records.

4. Entry or withdrawal of shareholders that hold, with the company, contract or operational, financial, technological or administrative collaboration.

5. Authorization for trading of securities issued by the company in any domestic or foreign market. Relevant acts or facts concerning the decision, approval, authorization, and other information were also considered in this item.

6. Decision to cancel the registration of a public company.

7. Incorporation, merger or spin-off involving the company or related companies. Relevant acts or facts concerning the acquisition, corporate restructuring and corporate reorganization were also considered in this item.

8. Transformation or dissolution of the company.

9. Change in the company's assets. Relevant acts or facts concerning the issue of shares, issuance of debentures, issue of promissory notes, and sale of equity interest were also considered this item.

10. Changes in accounting criteria;

11. Renegotiation of debts; 
12. Granting plan approval of stock option purchase;

13. Change in the rights and advantages of securities issued by the company;

14. Split or reverse stock-split or bonus attribution;

15. Acquisition of company shares for holding in treasury or cancellation, and the sale of shares so acquired;

16. Profit or loss of the company and the allocation of cash dividends. Relevant acts or facts concerning the distribution of dividends and payments of interest on own capital - IOC, were also considered in this item.

17. Celebration or termination of contracts or the failure to execute when the expectation is of public knowledge;

18. Approval, alteration or abandonment of a project or delay in its implementation.

19. Beginning, retaking or suspending the manufacturing or sale of products or provision of service.

20. Discovery, change or development of technology or company resources.

21. Modification of projections disclosed by the company.

22. Filing for bankruptcy, petition or confession of bankruptcy, or any lawsuit that may affect the financial position of the company.

23. Other relevant acts or facts or different market communications.

Source: Instruction CVM no 358/02 with adaptations by the authors (2012).

Some of the listed items were adapted and deserve the following clarifications:

- Regarding item 5 - authorization for trading of securities issued by the company in any market, domestic or foreign - if the company decides to go public in international markets and meets the prerequisites for, e.g., trading securities on US stock exchange, the company should disclose this information to the Brazilian market. These disclosures were also considered.

- On item 7 - incorporation, merger or spin-off involving the company or related companies - also took up the relevant facts relating to restructurings and corporate reorganizations. The increase in these restructuring operations in Brazil is noticeable, derived of globalization, the development of the capital market and the increasing volume of internal and external investments (CARDOSO, 2006), which justifies the increased disclosure.

- With regard to item 9 - changes in the company's assets - all information concerning the issue of shares, debentures, promissory notes and sales of shareholdings has been incorporated ; situations that characterize changes in organizational assets. The same justification proceeds to item 16 - profit or loss of the company and the allocation of cash dividends - for this item all information disclosed by companies related to payments of dividends and interest on equity was considered.

- The 22 relevant facts of CVM Instruction No. 358/02 item 23 was included - other relevant acts or facts or different market communications. As already described, the relevant information disclosure policy includes aspects related also to other content that complement its disclosure (CODIM, 2008). Thus, in paragraph 23, information relating to the accounts of administrative and specific management decisions of the senior management of the company has been considered.

After the classification of 1,125 relevant information the frequency of the relevant facts by company and by sector and occurrences of the disclosure of information by content of the material fact was calculated. The next step was analyzing the correlation between the number of relevant facts informed and the years and months of disclosure and sectors of the surveyed organizations. The results are discussed in the session that follows. 


\section{DESCRIPTIONS OF THE RELEVANT FACTS OF BRAZILIAN OPEN CAPITAL COMPANIES ISSUERS OF ADRS}

The descriptive statistical analysis of the relevant acts and facts of Brazilian companies that trade ADRs are divided into two sessions. The first addresses the frequency of disclosure of such information by business and industry, taking into account also the occurrences of governance market segment. In the second stage it is analyzed the correlation between the frequency of the relevant facts announced to the market with the periodicity (annual and monthly), as well as sectors and categories referred to in the legislation. The first analysis refers to the frequency of relevant acts and facts by company disseminated by organizations surveyed from January 2006 to April 2012 (TAB. 1).

It is noted that Vale S/A is the company that most discloses relevant acts and facts, followed by Petrobras, Companhia Siderurgica Nacional and Itaú Unibanco Holding S/A together, the four companies account for $32.1 \%$ of all relevant acts and facts disclosed by Brazilian organizations in this period. Embraer, Gol and Copel are the companies that least disclose relevant information. Among the five companies with the largest frequency of relevant disclosures, two are listed in governance segment of the BM \& FBOVESPA - S.A. Vale and Itau Unibanco Holding S/A (Level1). If we analyze the five companies that least disclose important information, interestingly, four organizations are also listed in governance levels of the Brazilian stock market - Embraer (New Market), Gol and Santander (Level2) and Copel (Level1).

TABLE 1- Frequency of relevant facts by company

\begin{tabular}{|c|c|c|c|}
\hline \multicolumn{4}{|c|}{ Number of relevant facts by companies from 2006 to 2012} \\
\hline COMAPANIES & FREQUENCY & PERCENTAGE \% & ACCUMULATED \\
\hline Vale S. A. & 138 & 12,3 & 12,3 \\
\hline Petrobrás & 110 & 9,8 & 22,1 \\
\hline Cia Siderúrgica Nacional & 57 & 5,1 & 27,2 \\
\hline Itau Unibanco Holding S. A. & 56 & 4,9 & 32,1 \\
\hline Tele Norte Leste Participações & 49 & 4,4 & 36,5 \\
\hline Brasil Telecom & 44 & 3,9 & 40,4 \\
\hline Brasken & 42 & 3,7 & 44,1 \\
\hline Cemig & 42 & 3,7 & 47,8 \\
\hline BR FOODS & 38 & 3,4 & 51,2 \\
\hline Fibria & 38 & 3,4 & 54,6 \\
\hline Bco. Bradesco & 38 & 3,4 & 58,0 \\
\hline Brasil Telecom Participações & 38 & 3,4 & 61,4 \\
\hline Gafisa & 37 & 3,3 & 64,7 \\
\hline Aracruz & 34 & 3,0 & 67,7 \\
\hline Sadia S A & 28 & 2,5 & 70,2 \\
\hline Net Serviços de Telecomunicações & 27 & 2,4 & 72,6 \\
\hline CPFL & 26 & 2,3 & 74,9 \\
\hline COSAN & 24 & 2,1 & 77,0 \\
\hline TIM & 24 & 2,1 & 79,1 \\
\hline Ultrapar Participações & 24 & 2,1 & 81,2 \\
\hline VIVO & 24 & 2,1 & 83,3 \\
\hline Cia Brasileira de Distribuição & 24 & 2,1 & 85,4 \\
\hline SABESP & 23 & 2,0 & 87,4 \\
\hline Gerdau S.A. & 21 & 1,9 & 89,3 \\
\hline Tele Norte Celular Participações & 19 & 1,7 & 91,0 \\
\hline Telemig & 18 & 1,6 & 92,6 \\
\hline TAM & 17 & 1,5 & 94,1 \\
\hline Telesp & 14 & 1,2 & 95,3 \\
\hline GOL & 13 & 1,2 & 96,5 \\
\hline Embraer & 12 & 1,1 & 97,6 \\
\hline AMBEV & 12 & 1,1 & 98,7 \\
\hline Bco. Santander & 11 & 0,9 & 99,6 \\
\hline Copel & 3 & 0,4 & $100 \%$ \\
\hline TOTAL & 1.125 & $100 \%$ & \\
\hline
\end{tabular}

Source: Research Data (2012)

The TAB. 2 displays the frequency of relevant acts and facts by each company and sector. 
Among the business sectors, the industrial sector and the natural resources sector have the largest concentration of listed companies in the fields of corporate governance, i.e. 5 companies in each sector. Of the 10 companies involved in the industrial sector, two are in Level1 and three in New Market. In the resource sector there is an inversion, where three companies listed in Level1 and two in New Market. All of the financial services sector companies appear listed in the segments of corporate governance, two companies in Level1 and Level2. Regarding the service sector, $60 \%$ of related companies are classified in governance Level, being a company in Level2 and two in New Market, in this group there is no incidence of companies in Level1. Of the 9 companies in the telecommunications sector, only Net Services and TIM appear listed in corporate governance segment, the first in Level2 and the second in New Market.

TABLE 2- Frequency of relevant facts by company and by sector

\begin{tabular}{|c|c|c|c|c|c|}
\hline SECTOR & COMPANIES & FREQUENCY & PERCENTAGE & ACCUMULATED & $\begin{array}{c}\text { GOVERNANCE } \\
\text { LEVEL }\end{array}$ \\
\hline \multirow{7}{*}{ Natural Resources } & Vale & 138 & 40,2 & 40,2 & Level1 \\
\hline & Petrobrás & 110 & 32,1 & 72,3 & - \\
\hline & Cemig & 42 & 12,2 & 84,5 & Level1 \\
\hline & CPFL & 26 & 7,6 & 92,1 & New Market \\
\hline & Ultrapar & 24 & 7,0 & 99,1 & New Market \\
\hline & Copel & 3 & 0,9 & 100 & Level1 \\
\hline & TOTAL & 343 & 100 & & \\
\hline \multirow{11}{*}{ Industry } & $\mathrm{CSN}$ & 57 & 18,6 & 18,6 & - \\
\hline & Brasken & 42 & 13,7 & 32,3 & Level1 \\
\hline & BR FOODS & 38 & 12,4 & 44,7 & - \\
\hline & Fibria & 38 & 12,4 & 57,1 & New Market \\
\hline & Aracruz & 34 & 11,1 & 68,2 & - \\
\hline & Sadia & 28 & 9,3 & 77,5 & - \\
\hline & Cosan & 24 & 7,8 & 85,3 & New Market \\
\hline & Gerdau & 21 & 6,9 & 92,2 & Level1 \\
\hline & Embraer & 12 & 3,9 & 96,1 & New Market \\
\hline & Ambev & 12 & 3,9 & 100 & - \\
\hline & TOTAL & 306 & 100 & & \\
\hline \multirow[t]{6}{*}{ Services } & Gafisa & 37 & 32,5 & 32,5 & New Market \\
\hline & Cia Brasileira de Distribuição & 24 & 21,0 & 53,5 & \\
\hline & TAM & 17 & 14,9 & 68,4 & \\
\hline & SABESP & 23 & 20,2 & 88,6 & New Market \\
\hline & GOL & 13 & 11,4 & 100 & Level2 \\
\hline & TOTAL & 114 & 100 & & \\
\hline \multirow[t]{4}{*}{ Financial Services } & Itau Unibanco & 56 & 53,3 & 53,3 & Level1 \\
\hline & Bco. Bradesco & 38 & 36,2 & 89,5 & Level1 \\
\hline & Bco. Santander (Brasil) & 11 & 10,5 & 100 & Level2 \\
\hline & TOTAL & 105 & 100 & & \\
\hline \multirow[t]{10}{*}{$\begin{array}{l}\text { Telecommunication } \\
\mathrm{s}\end{array}$} & $\begin{array}{lll}\text { Tele } & \text { Norte } & \text { Leste } \\
\text { Participações } & \\
\end{array}$ & 49 & 19,1 & 19,1 & - \\
\hline & Brasil Telecom & 44 & 17,1 & 36,2 & - \\
\hline & Brasil Telecom Participações & 38 & 14,8 & 51,0 & - \\
\hline & NET SERVIÇOS & 27 & 10,5 & 61,5 & Level2 \\
\hline & VIVO & 24 & 9,3 & 70,8 & - \\
\hline & TIM & 24 & 9,3 & 80,1 & New Market \\
\hline & TELE Norte Celular & 19 & 7,4 & 87,5 & - \\
\hline & TELEMIG & 18 & 7,0 & 94,5 & - \\
\hline & TELESP & 14 & 5,5 & 100 & - \\
\hline & TOTAL & 257 & 100 & & \\
\hline
\end{tabular}

Source: Research data (2012).

Following the results regarding the nature of the relevant acts and facts are analyzed.

As shown in TAB. 3 items 7 - incorporation, merger or spin-off involving the company or related companies; 23 - other acts or facts identified and not listed in the normative instruction; 16 - Profit or loss of the company and the allocation of cash dividends; 5 authorization for trading of securities issued by the company in any domestic or foreign market; 9 - change in the company's assets; 17 - celebration or termination of contracts or the 
failure to execute when the expectation is of public knowledge and; 15 - acquisition of company shares for holding in treasury or cancellation, and the sale of shares so acquired, had, in that order, the highest incidence of facts reported by organizations, accounting for $82 \%$ of total items disclosed in the 2006 period to April 2012.

It is worth noting the sharp increase in disclosure of facts related to executive compensation in the 2011/2012 period, especially from Vale, which reflected the increased frequency of relevant information of item 23. This is also due to the rigor imposed by US law for the trading of ADRs (KPMG, 2012).

TABLE 3 - Cumulative Frequency of relevant facts published between 2006 and 2012

\begin{tabular}{|c|c|c|c|}
\hline RELEVANT FACT & FREQUENCY & $\%$ & ACCUMULATED \\
\hline 7 & 321 & 28,5 & 28,5 \\
\hline 23 & 219 & 19,5 & 48,0 \\
\hline 16 & 107 & 9,5 & 57,5 \\
\hline 5 & 93 & 8,3 & 65,8 \\
\hline 9 & 88 & 7,8 & 73,6 \\
\hline 17 & 53 & 4,7 & 78,3 \\
\hline 15 & 42 & 3,7 & 82,0 \\
\hline 3 & 36 & 3,2 & 85,2 \\
\hline 12 & 31 & 2,8 & 88,0 \\
\hline 13 & 20 & 1,8 & 89,8 \\
\hline 18 & 20 & 1,8 & 91,6 \\
\hline 14 & 20 & 1,8 & 93,4 \\
\hline 1 & 16 & 1,4 & 94,8 \\
\hline 20 & 15 & 1,3 & 96,1 \\
\hline 21 & 11 & 1,0 & 97,1 \\
\hline 11 & 10 & 0,9 & 98,0 \\
\hline 19 & 6 & 0,5 & 98,5 \\
\hline 10 & 5 & 0,4 & 98,9 \\
\hline 6 & 4 & 0,4 & 99,3 \\
\hline 2 & 3 & 0,3 & 99,6 \\
\hline 4 & 3 & 0,2 & 99,8 \\
\hline 8 & 1 & 0,1 & 99,9 \\
\hline 22 & 1 & 0,1 & 100,0 \\
\hline TOTAL & 1.125 & 100,0 & \\
\hline
\end{tabular}

Source: Research data (2012).

The relevant fact for the item 7 - incorporation, merger or spin-off involving the company or related companies is the most reported by surveyed Brazilian companies, representing $28.5 \%$ of all the relevant information identified between 2006 and April 2012. The resources sector natural was the one that showed most incidence of these events (88), followed by the sectors of industry (83) and telecommunications (76). The three mentioned sectors accounted for $80.5 \%$ of the disclosures in the period. In 2009 , there was a higher incidence of information takeovers, mergers, restructurings and corporate reorganizations. Of the 32 companies surveyed, Vale S/A was the one that reported facts relating to item 7, totaling 27 incidents in seven years.

All 33 companies analyzed in the period reported at least one relevant act or fact classified under item 23 - other relevant acts or facts or different market communications. The relevant fact 23, as explained above, was incorporated in this work to gather the information disclosed by companies that do not fit in any of the other 22 items provided for in CVM Instruction $358 / 02$. These disclosures totaled 219 events in the period. The sectors that disseminated information on item 23 were telecommunications with 57 disclosures and industry, with 48 . The natural resources sector in the last two years released 29 classified information in this item, and Vale is responsible for 19, Petrobras 9 and Cemig 1 . The sector that least reported classified information under item 23 was financial services with 11 disclosures in the period. 
The relevant information relating to item 16, profit or loss of the company and the allocation of cash dividends, are presented as the third most frequent fact of the data collected, with 107 incidents. In the past two years, the natural resources sector shows the largest number of incidences (24) followed by the financial services industry (21). The year 2006 represented the period of highest occurrence of disclosure permits for securities trading classified as item 5 by the CVM. Vale S/A, with 16 incidents, stands out as the company that disclosed the largest amount of this type of information to the market. With regard to the act or fact classified under item 9 - change in the company's assets - 88 information regarding this fact were released. In the last two years the sector that most reported asset composition changes was the industry.

Another stage of the statistical analysis was to check whether there is a correlation between the occurrence of the relevant facts with business, industry and periodicity (year and month) of its incidence. For the study population, it was not possible to assume the normality of the data, so the non-parametric tests were used. A nonparametric test is used when the sample is very small, when the assumptions for parametric tests are not met or if the data is coming from an unknown distribution (SIEGEL; CASTELLAN, 2006), a fact that occurred during the analysis of the data bank.

Analyzing the relevant acts and facts disclosed per year we can see a similarity in the number of reported facts. It can be said that there is not a big difference between the years studied and annual number of relevant acts and facts disclosed. This demonstrates that there is homogeneity between the relevant facts to numbers released annually in the period. The results of the Kruskal-Wallis test indicated a very high P-value, which shows the absence of a significant difference between the observed years and the number of events reported per year.

Examining the average number of relevant facts by sector, it was found out that there is a similarity between the means of industry, financial services and telecommunications sectors. The natural resources sector has the highest average of material facts disclosed and the financial services sector the lowest. Through the Kruskal-Wallis test it was possible to verify that there is no significant difference in the disclosure of facts between sectors.

\section{FINAL CONSIDERATIONS}

The goal that guided this article aims to identify and evaluate relevant information that Open capital Brazilian companies issuers of ADRs disclose to meet the legal guidelines of the agencies that regulate the securities market. The relevant facts with higher incidence of disclosure were the corporate restructuring operations, specifically those relating to the incorporation, merger or spin-off involving the company or related companies. This is due in part to the large volume of incorporation of companies has been moving the business sectors since the beginning of the century. It is worth noting the number of occurrences from Vale, a company that has chosen to become global through acquisitions strategies; and the telecommunications industry, which went through an intense movement of incorporations in the surveyed period.

The second highest incidence refers to the group - other relevant acts or facts and several announcements to the market - that is, those who do not meet the 22 items set out in normative instruction of the Securities and Exchange Commission. Under legal regulation, it has the list contained in CVM Instruction 358/02 does not restrict the chances of relevant acts or facts to be disclosed. As much as the normative text consider the legislation "not exhaustive" and "exemplary", the classification of the relevant facts, the diversity of the nature of the reported events affect the framework of those administrative character narratives and on 
specific management decisions from senior management of the company . Brazilian sectors of natural resources and industrial are the ones who had the most impact on this information.

Profit or loss of the company and the allocation of earnings and authorization for securities trading are the two relevant facts that appear in the sequence in terms of the number of occurrences. In the case of the fact - profit or loss of the company and allocation of dividends the disclosures of the natural resources account for over $50 \%$ of the information disclosed to the market. The good results of the sector, in particular, before the recent financial crisis that affected the world commodity market, contributed to the high number of reports on the distribution of dividends to the shareholders of these companies. No company made mention of the damage term in the disclosure of information to the market in the surveyed years. However, the industry sector, excluding only a report in the telecommunications industry, was the one who released information regarding debt renegotiations.

In relation to changes in equity composition the sectors of natural resources, industry and telecommunications accounted for almost $80 \%$ of the disclosure of these facts. The high volume of corporate restructuring disclosed to the market may explain the amount of information proceeded by these two sectors. With regard to the disclosure of acquisition of shares to be held in treasury operations that aim to influence, in a limited way, liquidity and share price, the CIA. Siderúrgica Nacional is the company that most reports on the use of the purchase mechanism of its own shares. In terms of sectors, the industry sector is the one the most disseminates information on the acquisition of their own securities.

If we consider the assumption that companies operating in markets where the exercise of good governance practices is demanded disclose more information than those listed organizations in traditional markets, we will see through the research's results that in the Brazilian securities market, not necessarily the companies that trade their securities in these markets, disclose a greater amount of information than other industry organizations. The principle of transparency, it is apparent that the larger the size of the company, the greater the Level of disclosure (disclosed information). This finding goes against the literature that indicates that large companies tend to have higher degree of disclosure in the disclosure of information (Shleifer, Vishny, 1986; DANTAS; ZENDERSKY; SANTOS; NIYAMA, 2005). The two largest Brazilian organizations in size and performance are the ones that most disclose relevant information.

The correlation between the occurrences of the relevant facts on periodicity that they are released showed no heterogeneity between the number of reported facts and the amount of information available on the market each year, that is, an annual consistency in disclosure prevails. The same cannot be said for the monthly. There is a concentration of disclosures in the months of April and December and a lower incidence in February and September. If we consider the average volume of relevant information disclosed to the market, the natural resources sector, followed by telecommunications sectors and industry were the ones that most provided information of their actions. Correlation tests ruled out significant relationship between the disclosure of a particular type of material fact with some sector or reporting period.

Some other observations can be performed on the collected data. The non-disclosure of relevant reports strategies mentioned by Oliveira, Lopes and Cunha (2008) can be identified in the fact - profit or loss of the company and the allocation of cash dividends. Among the 33 companies analyzed, only nine have explicitly declared that dividends or interest on capital 
have been paid to shareholders in the analyzed period. According to the normative instruction, even if the company has not distributed cash dividends in the period, it must be shown for the annual results of operations; hence, in some cases, the prevailing duality of the benefits of full disclosure about the company and the reluctance to disclose strategic information. Information is relevant depending on its degree of importance and necessity.

This study is an overview of how companies that operate in the US stock market, which requires high Level of transparency in the disclosure of information, have complied with the guidelines determined by the regulatory agencies. Even with the large and complex volume of information made available by open capital organizations, there is a growing trend to increase supervision over the quality of information that have been provided. In particular, in the US stock market, with the advent of Dott-Frank Act, seems imminent the elevation of means of control over the dissemination of information of companies. The reflections on the survey results point to evidence that even with the legal pressure on the regular disclosure of relevant information from national and international stock markets, the volume of information provided is in a lower average than the organizations that operate in traditional securities markets.

\section{References}

ANSOFF, I.; MCDONNELL, E. J. Implantando an administração estratégica. São Paulo: Atlas, 1993.

BHATTACHARYA, N. E.; BLACK, E. L.; CHRISTENSEN, T.; MERGENTHALER, R. 2007. Who trades on pro forma earnings information? The Accounting Review, 82 (3): 581-619.

BORGERTH, V.M.C. Sox. Entendendo a Lei Sarbanes: Oxley. São Paulo: Thomson, 2007.

BOWEN, R., DAVIS, A., MATSUMOTO, D., 2005. Emphasis on pro forma versus GAAP earnings in quarterly press releases: Determinants, SEC intervention, and market reactions. The Accounting Review 80 (4): 1011-1039.

BRASIL. Lei no. 6.404, de 15 de dezembro de 1976. Dispõe sobre as sociedades por ações. Diário Oficial da União, 17 dez. 1976.

Lei no. 6.385, de 7 de dezembro de 1976. Dispõe sobre o mercado de valores mobiliários e cria a Comissão de Valores Mobiliários. Diário Oficial da União, 9 dez. 1976.

BROWN, M. C.; THEODORE, E.; CHRISTENSEN, W.; BROOKE, E. The timing of quarterly 'pro forma' earnings announcements. Journal of Business Finance \& Accounting. Volume 39, Issue 3-4, p. 315-359, april-may, 2012.

CARDOSO, O. Onésimo. Comunicação empresarial versus comunicação organizacional: novos desafios teóricos. Revista de Administração Pública, Rio de Janeiro, v. 40, n.6, Nov. /dec. 2006.

CODIM - COMITÊ DE ORIENTAÇÃO PARA DIVULGAÇÃO DE INFORMAÇÕES AO MERCADO. O que é o CODIM. 2008. DispoLevelem: <http://www.codim.org.br/CODIM.asp?pg=oq ue.htm>. Acesso em: 25 Jan. 2010.

CVM - COMISSÃO DE VALORES MOBILIÁRIOS. Instrução Normativa no 31, de 08 fev. 1984. Dispõe cerca da divulgação e do USO de informações sobre ato ou fato relevante relativo às companhias abertas. DispoLevelem: <www.cvm.gov.br>. Acesso em: 21 fev. 2012. Jan. 2012.

Instrução Normativa no 358 de 03 de janeiro de 2002. DispoLevelem <www.cvm.gov.br>. Acesso em: 11

DANTAS, J. A.; ZENDERSKY, H. C.; SANTOS, S. C.; NIYAMA, J. K. A dualidade entre os benefícios do disclosure e a relutância das organizações em aumentar o grau de evidenciação. E \& G Economia e Gestão, Belo Horizonte, v. 5, n. 11 , p. 56-76, dez. 2005.

DAVIS, A. K.; PIGER, J.; SEDOR, L. M. Beyond the numbers: measuring the information content of earnings press releases. Contemporary Accounting Research. Volume 29, Issue 3, pages 845-868, September, 2012.

DEFOND, M.; HUNG, M.; TREZEVANT, R. Investor protection and the information content of annual earnings announcements: International evidence. Journal of Accounting and Economics, vol. 43, issue 1, pages 37-67, 2007. 
Loures, L.L., Goncalves, C.A. \& Pardini, D.J. (2017). Dsiclosure of Relevant Acts or Facts: A Study of Brazilian Companies Issuing American Deposit Receipts - Adrs at American Stock Exchange. Archives of Business Research, 5(1), 135-148.

FRANCIS, J.; SCHIPPER, K.; VINCENT, L. Expanded disclosures and the increased usefulness of earnings announcements. The Accounting Review, v. 77, n. 3, p. 515-546, 2002.

GRUN, Roberto. Atores e ações Na construção da governança corporativa brasileira. Revista Brasileira de Ciências Sociais, v. 18, n. 52, p. 139-161, jun. 2003.

GUEDES, T. A.; MARTINS, A.B.T.M. Projeto de ensino: aprender fazendo estatística. DispoLevelem: <http://www.scribd.com/doc/1880799/Estatistica-Descritiva>. Acesso em: 02 out. 2010.

KPMG. A governança corporativa e o mercado de capitais: um panorama atual das corporações brasileiras Na Bovespa e nas bolsas norte-americanas. [s.l.]: KPMG, 2011/2012. 54p.

LANZANA, A. P.; SILVEIRA, A. M.; FAMÁ, R... Existe relação entre disclosure e governança corporativa no Brasil? In: XXX ENANPAD 2006, Salvador - BA. Anais ..., 2006.

LESCA, H.; ALMEIDA, F. C. Administração Estratégica da Informação. Revista de Administração da USP - RAUSP, v. 29, n.3, p.66-75, Jul. /set. 1994.

LOPES, C. E.; VALENTIM, L. P. M. Mediação da informação no âmbito do mercado de capitais, Informação \& Informação. Londrina, v.13, p. 87-106, 2008.

MESQUITA, J. M. C. Estatística Multivariada Aplicada à Administração: guia prático para utilização do SPSS. Curitiba: Editora CRV, 2010. 167 p.

OLIVEIRA, H. M. S.; LOPES, C. M. F. P.; CUNHA, C. A. S. A transparência da informação por parte dos emitentes. Revista Universo Contábil, Blumenau, v. 4, n. 2, p. 93-104, abr. /jun. 2008.

POLK, Davis; LLP, W. Summary of the Dodd-Frank Wall Street Reform and Consumer Protection Act, Enacted into Law on July 21, 2010, ii (July 21, 2010). DispoLevelem: <http://www.davispolk.com/files/Publication/7084f9fe6580-413bb870 b7c025ed2ecf/Presentation/PublicationAttachment/1d4495c7-0be0-4e9a-ba77

f786fb90464a/070910_Financial_Reform_Summary.pdf> Acesso em: 03 Jan. 2011.

SCHRAND, C. M.; WALTHER, B. R. Strategic benchmarks in earnings announcements: the selective disclosure of prior-period earnings components. The Accounting Review. V. 75. n. 2. Pp-151-177. Abr. 2000.

SIEGEL, S.; CASTELLAN, N. J. Estatística não-paramétrica para ciências do comportamento. 2. ed. Porto Alegre: Artmed, 2006. 448p.

SHLEIFER, A.; VISHNY, Robert. Large shareholders and corporate control. Journal of Political Economy, v. 94, p. 461-488, 1986.

SILVA, C. A. T.; FELIPE, E. S. Avaliação da influência de textos narrativos de fatos relevantes no preço das ações de empresas brasileiras. Revista de Contabilidade e Controladoria. v. 2, n.6, pp.61-80. 2010.

SON, M.; CRABTREE, A. D. Earnings Announcement Timing and Analyst Following. Journal of Accounting, Auditing \& Finance, Vol. 26, No. 2, pp- 443-468. 2011.

UNITED STATES OF AMERICA. 111 Th United States Congress. Dodd-Frank wall street reform and consumer protection act, public law 111 -203-July 21, 2010. Washington, D.C., 2010. DispoLevelem:

<http://frwebgate.access.gpo.gov/cgi-bin/getdoc.cgi?dbname=111_cong_public_laws\&docid=f:publ203.111.pdf>. Acesso em: 03 in 2012. 